\title{
GROWTH OF E-MARKETING IN INDIA
}

\author{
DR. KULDEEPWALIA \& MS. JASPREET KAUR
}

Assistant Professor, Department of Economics, SGGSW University, Fatehgarh Sahib, Punjab

\begin{abstract}
E-marketing has been around us for about fifteen years. It grows rapidly with the emergence of Google in the early 2000s. In simple terms, electronic marketing involves product marketing via various online platforms on the internet. Internet has made the world a global village for the business community around the world. Customers can always keep in touch and see what companies are updating about their services and products every other time. Nowadays, companies in the Americas or Europe can effectively advertise their services and goods to potential clients/customers in Africa or Asia. Doing business has never been easier, e-marketing has made it easier to reach out to new markets and this promotes international trade by opening new markets that never existed.

KEYWORDS: E-Marketing, International Trade
\end{abstract}

Received: Jun 08, 2020; Accepted: Jun 28, 2020; Published: Aug 31, 2020; Paper Id.: IJMPERDJUN2020984

\section{INTRODUCTION}

E-marketing has been around us for about fifteen years. It grows rapidly with the emergence of Google in the early 2000s. In simple terms, electronic marketing involves product marketing via various online platforms on the internet. Internet has made the world a global village for the business community around the world. Customers can always keep in touch and see what companies are updating about their services and products every other time. Nowadays, companies in the Americas or Europe can effectively advertise their services and goods to potential clients/customers in Africa or Asia. Doing business has never been easier, e- marketing has made it easier to reach out to new markets and this promotes international trade by opening new markets that never existed.

Indian market changed entirely with the emergence of e-marketing. The increasing rate of internet and mobile users smooth the progress of the e-market in rural India. Indian e-market attracted a huge sum of foreign direct as well as indirect investment. 'In July 2014, Amazon invested \$2 billion in India, following the news of Flipkart raising $\$ 1$ billion in funding'(Bijlan\& Singh, 2015).Today, there are a number of e-companies in Indian emarket. Some of these giants, earning a handsome profit are Amazon,Snapdeal, Flipkart,Jabong, Craftsvilla, Mantra etc. Annual growth rate in e- retail is so attractive (approximately 40-50 percent) that many indigenous offline businesses every year diversify their business to online. Recent example is Reliance retail market that starts their online shore with the name of Jio Mart. As entry of new companies is escalating, the competition is also going to be cut throat.Consumer is King here and only those survive who serve best.Price and Quality both matter.

\section{Key Developments}

- According to theIndian E-Commerce Industry Report, May 2020, 'it is expected that the Indian e-market which had a capital of US\$ 38.5 billion in 2017, would be grow to a capital of US\$200 billion by 2026 . The growth rate of Online retail market is 31 percent with an assets of US\$ 32.70 billion in 2018." 
- Report depicts some key developments of Indian e-market e.g.

- According to Report, Primary testing of food and grocery app of Reliance group is going on. ( later, it launched as Jio Mart in May 2020)

- In January 2020, Divine Solitaires commenced its e-marketing shore.

- Internet and mobile services are base of e-market. Under Union Budget 2020-21, Rs. 8000 crore is allocated for Bharat Net Project. This project will facilitate broadband services 150,000 village local bodies.

- In August 2019, 49 percent shares of Future Group were acquired by e-market giant Amazon.

- Reliance announced that it will invest Rs. 20,000 crore to develop 5G services in India.

- In September 2019, 'Switch' app was launched as a one window for all merchant apps. It was an initiative of 'PhonePe'.

- Walmart, a US based giant, purchased Flipkart for US\$16 billion. Now, Flipkart is going to open offline fashion and electronic stores in India.

- In March 2019, Flipkart announced that it raised internal funds of approximately US\$ 60 million to spend on R\&D for growth of e-marketing in India.

- India's first online bank with zero balance and free virtual debit card had been launched by Paytm, called Paytm Payment Bank.

- 'Internet Saathi' was a social project which helps to increase the access of internet to rural women. It was a joint initiative of Tata Trust and Google.With this venture more than 26 million ladies have an access to internet in India and it reached to 2.6 lakh towns of 20 states.

- Since 2014, various programshave been launched by India Government to promote e-commerce. Some of these are: Digital India, Make in India, Start-up India, Skill India and Innovation Fund.

- Since 2014, web based business enterprises have made sure about over $\$ 3.9$ billion speculation from investor and private value firms and interior funders.

- Chinese E-Commerce Company Alibabacollaborate withZhyianto put about \$575 million in One97 correspondence Limited likewise known Patym. Paytm offers portable installment, in addition to it permits client to purchase tickets, arrangements and shop from its 1800 traders in its system.

- In December 2014, Japanese web company Softbank announced its plan to invest $\$ 10$ billion in India.the company has already 30 percent share in Snapdeal and Housing.com.

\section{Determinants of Growth}

The key driver of growth of Indian e-market isrevolutionary growth in use of internet. The factors behind empowering development of internet are given as follows:

- Rising ways of life notwithstanding it, there is an expansion in yearly family unit salary. 
- $\quad$ Outside Speculators are subsidizing online business part because of solid development possibilities.

- $\quad$ Falling correspondence cost, huge populace bought in to web broadband and $4 \mathrm{G}$.

- Expanded utilization of Cell phone, I-pad and tablets advance development of e-market in addition to the vast majority of the spending originates from cell phones.

There are extensively two types of e-market. The first type is the place the satisfaction is implicit. There is an entire group of traded goods and services where the client need is satisfied by means of the Internet. Like advanced media (music, motion pictures, digital books), Apps, Electronics and machines, Fashion, Books, programming, tagging (travel, films, shows), coordinating partners (marriage, dating, cab services), and others.In such zones where the satisfaction is implicit, the Internet has a gigantic favorable position over customary methods of working together and the vast majority is aware of this. The second type of e-market is the place the satisfaction of the customers' needs to occur in reality. This is the place things become to some degree complicated. E-business has both favourable and unfavourable circumstances. Favorable circumstances identify as more extensive options to clients, effective stock administration, inferior search and grating costs, enhanced access for clients, lower staffing and hire expenses. The key classes in second type of e-market are travel, personal computers, mobile accessories, consumer durables, jewellery, textiles, health \& beauty products, cars, real estate and investment.Lifestyle and fashion segment has consistently stayed probably the most smoking class for online purchasers.

The recent trends show that e-market is ascending the stepping stool of achievement at a fast pace. A report by Internet Mobile Association of India uncovered that India's e-market is developing at a normal pace of 70 percent every year and has developed more than 500 percent since 2007.

\section{E-Market Contributes to Other Sectors of Economy}

- It expanded business of Credit Cards. An ongoing report by the Boston Consulting Group (BCG) evaluated that the credit card industry is witnessing around 26 to 27 percent development in total e-market spendings. As per the most recent information accessible on the RBI site HDFC Bank Ltd is the pioneer both as far as the quantity of credit cards just as exceptional card advances. On the other hand, SBI Cards and Payment Services Pvt. Ltd has seen a 60 percent annual growth in credit card spending on e-business exchanges in 2015 . Websites offer many types of discounts and cash back schemes on credit card transactions, thus such transactions are popular than net banking and other methods of transactions. Growing size of e-market is probably to play an important role in future strategies of banking and credit card industry.

- It increased advertising revenue. Every e-company tries hard to attract more and more users to its website. For this, they spend a lot on advertisement. These selling costs are approximately two-thirds of the total capital raised by these e-business players. The position of e-commerce companies has been improving consistently. But it is also true that still today, conventional media i.e. Television, radio, newspapers etc. is brand builder. Internet has limited access and not able to create a similar buzz as conventional media. Most of the companies are new in market, so they have to rely on advertisement. Thus their selling costs probably increase in coming years. This will help to grow another part of industry i.e. advertisement companies.

\section{Challenges to the E-Market in India}


- E-market in India have been confrontingnumerousdifficulties like

- High rate of GST

- Occurrences of fraud and threat todigital security,

- Cut throat competition

- Customer in sub urban and rural India mostly prefer to pay in cash (COD)

- There is still lack of adequate infrastructure and digital illiteracy.

Due to high competition, e-companies have to serve best on low prices. But high GST rate of some consumer goods and tri system of GST raise-up the prices. Various episodes of supply of fake and cheap quality commodities by websiteshaveshaken the faith of consumers. There is lack of a reliable mechanism which may permit customers to check the authenticity of seller and his product. Threat to personal data and information is another challenge which faced by both consumers as well as seller. This personal information is either sell by websites to third party or steals by hackers. The communicated information use or misuse by third party. Consumers' preference to pay cash on delivery (COD) is another challenge for seller.Accepting payment after delivery makes the procedure relentless, dangerous and increasingly costly for the supplier as their working capital prerequisite increments. Goods sold online have a high rate of return. It is direct lose to companies. Request for return is much higher in COD as compared to other transaction methods.

There is high competition in Indian e-market, which thusly has constrained organizations to implement aggressive price policy, offering substantial discounts to consumers and high commissions to sellers and other middle men. Thus profit of a company suffers.

\section{Road Ahead}

Indian e-market provide source of finance, technical know-how and training to medium and small scale industry. Thus it has favorable effect on MSME in India which trickle up to large industry. The Indian e-market is growing so fast that it is expected that by 2034 it will outperform the US to turn into the second biggest e- market after China (TET, 2016). Innovation empowered advancements like online transaction, hyper-nearby coordination, investigation driven client commitment and digital advertisement will probably support the development in market. The growth in e-marketing will likewise increaseemployment, increment incomes from trade, increment tax revenue by ex-chequers, and offer better commodities and services to clients in the long time.

\section{REFERENCES}

1. Agarwal, Sugandha (2015, November). E-Commerce in India on an Upswing. International Journal for Research and Scientific Innovations, II(XI).IJRSI ISSN 2321 - 2705

2. Agarwal,Ranjana (2014, Feb 1), Entrepreneurship in India: The Case of e-Tailing Ventures.International Journal of emerging technology and advanced engineering.4(I).e-ISSN 2250-2459.ICADET-14. India.

3. Agarwal,Sapna (2015, Feb 10). "Online retail to catch up with physical stores in 5 years: report”, liveMint, pp-11. https://www.livemint.com/Industry/NvVOIGkwPtEFixqgaplOFM/Online-retail-to-catch-up-with-physical-stores-in-five-years.html

4. Arora, Jyoti (2013).Prospect of E-Retailing in India.IOSR Journal of Computer Engineering (IOSR-JCE). 10(3).e-ISSN: 2278-0661, p- ISSN: 2278-8727. pp. 11-15.

5. Asthana, Shishir (2014, Nov 12). "5 things you didn't know about India's e -commerce industry", Business standard. 
6. https://www.business-standard.com/article/companies/5-things-you-didn-t-know-about-india-s-e-commerce-industry-114111201035_1.html

7. Baskar, D. (2013). An Exploratory Study on Electronic Retailing in India.International Journal of Scientific Research and Management (IJSRM), Special Issue on e-Marketing Road Ahead of India, pp.39-43.

8. Bijlan,Jitesh\& Sangeeta Singh (2015, Feb).E-commerce in India Accelerating Growth. Pwc India, https://www.pwc.in/assets/pdfs/publications/2015/ecommerce-in-india-accelerating-growth.pdf

9. Kapoor, Deepa (2014, Feb). E-Tailing: A Case Study on Myntra.com. Indian Journal of Applied Research and Management. 4(2). ISSN 2249-555X

10. Tyagi, Kumar lokinder\& Gera Navneet (2013, March).Impact of CRM in e-tailing industry In India: A Customer Perception Study.International Journal of Management and Economics.1(7).ISSN: 2231 - 4687.

11. Idema, Matthew (2015, Feb 23).Digital Marketing Trends in the New Year.Business World.pp. 34, 35.

12. [IEIR, 2020]. Indian E-Commerce Industry Report, May 2020. Accessed from https://www.ibef.org/industry/ecommerce.aspx

13. [TET] (2016, Dec 05). India to Overtake US as World's Largest E-Commerce Market: Study. The Economics Timeshttps://economictimes.indiatimes.com/industry/services/retail/india-to-overtake-us-as-worlds-largest-e-commerce-marketstudy/articleshow/55819926.cms? from $=m d r$

14. Thakkar Rajeev (2015, March 20).A Framework to Understand the E-Commerce Exuberance. MINT, pp.20 
